\title{
Nursing Activities Score: trajectory of the instrument from paper to cloud in a university hospital
}

\author{
Nursing Activities Score: trajetória do instrumento do papel à nuvem em um \\ hospital universitário \\ Nursing Activities Score: trayectoria del instrumento del papel a la nube en un \\ hospital universitario
}

How to cite this article:

Camargo MD, Silveira DT, Lazzari DD, Rodrigues AFV, Moraes KB, Duarte ERM. Nursing Activities Score: trajectory of the instrument from paper to cloud in a university hospital. Rev Esc Enferm USP. 2021;55:e20200233. DOI: https://doi.org/10.1590/1980-220X-REEUSP-2020-0233

\section{Maximiliano Dutra de Camargo ${ }^{1}$ \\ Denise Tolfo Silveira² \\ Daniele Delacanal Lazzari ${ }^{3}$ \\ D Alisson Fransciso Vargas \\ Rodrigues $^{4}$ \\ Katia Bottega Moraes ${ }^{5}$ \\ Erica Rosalba Mallmann Duarte ${ }^{6}$}

${ }^{1}$ Universidade Federal de Santa

Catarina, Florianópolis, SC, Brazil.

${ }^{2}$ Universidade Federal do Rio Grande do Sul, Departamento de Enfermagem Médico Cirúrgico, Porto Alegre, RS, Brazil.

${ }^{3}$ Universidade Federal de Santa Catarina,

Programa de Pós-graduação em Enfermagem, Florianópolis, SC, Brazil.

${ }^{4}$ Hospital Santa Casa de Misericórdia de Porto Alegre, Porto Alegre, RS, Brazil.

${ }^{5}$ Hospital de Clínicas de Porto Alegre, Porto Alegre, RS, Brazil.

${ }^{6}$ Universidade Federal do Rio Grande do Sul, Programa de Pós-graduação em Saúde Coletiva, Porto Alegre, RS, Brazil.

\begin{abstract}
Objective: To report the process of organization and construction of an information technology structure named Nursing Activities Score (NAS) Cloud Technology ${ }^{\circledR}$. Method: This project was based on the life cycle theory and has enabled the development of technological production through software engineering. Results: The NAS Cloud Technology ${ }^{\circledR}$ was developed for remote and collaborative access on a website hosted by Google Sites ${ }^{\circledR}$ and protected in a business environment by the certified security and data protection devices Health Insurance Portability and Accountability Act (HIPPA). In 2015, this system received more than 10.000 submissions/month, totaling 12 care units for critical patients covered by the information technology structure, circa 200 nurses per day involved in the collection and hundreds of daily submissions, integrating the complete transition from paper to cloud. Conclusion: The development of NAS Cloud Technology ${ }^{\circledR}$ system has enabled the use of technology as a facilitating means for the use of Nursing care data, providing tools for decision-making on the nursing personnel sizing required for the care demands in the inpatient care units. The potential of cloud structures stands out due to their possibility of innovation, as well as low-cost access and high replicability of the information system.
\end{abstract}

\section{DESCRIPTORS}

Nursing Informatics; Information Systems; Nursing Staff; Workload; Nursing; Critical Care. 


\section{INTRODUCTION}

Given the increasingly complex health care processes, the need for Nursing care management aims at quality and safety of care. The organizational dimension in this management scenario is related to team supervision, activity coordination, and communication processes ${ }^{(1)}$. An adequate allocation of human resources is a challenge for the management of complex units and the care demand of patients in critical health condition is associated with the occurrence of adverse events, mortality, and increased hospital costs ${ }^{(2)}$.

Optimizing the necessary human resources to guarantee safe care depends on the mobilization of management strategies, incorporating the satisfaction of nursing professionals with their work and reduction of stress and burnout and internal conflicts. In this context, adequate personnel sizing is indispensable and the use of instruments for this favors improved working conditions ${ }^{(3)}$.

The Nursing Activities Score (NAS) ${ }^{(4)}$ is an internationally recognized instrument, validated in Brazil ${ }^{(5)}$, which enables assessing workload in intensive care units. It is composed by 23 items, subdivided into seven broad categories: basic activities, ventilatory, cardiovascular, renal, neurological, and metabolic support, and specific interventions. These describe a set of intensive nursing care activities, whose score is expressed in percentage. The 23 items include direct and indirect care activities. Each nursing activity is subject to a binary choice in 18 out of 23 items. The remaining five items are multiple-choice. This score reflects $81 \%$ of nurse working time and the remaining 19\% derive from interventions which are exclusively related to the severity of the patient's clinical condition ${ }^{(4-6)}$.

The Brazilian Health Regulatory Agency (ANVISA Agência Nacional de Vigilância Sanitária), which disposes of the minimal requirements for Intensive Care Units, establishes the necessity of care assessment through a Nursing Care Needs Classification System. The needs of Nursing care should be related to the number of available workers ${ }^{(7)}$. In this context, NAS indicates the minimal number of nursing professionals required to provide patient care in each work shift. However, the long time spent filling the instrument due to its numerous items, the lack of training for nurses to use it, understaffing, below what is preconized by the legislation, and the severity of patients' conditions might be considered hindrances for the application of NAS in ICU ${ }^{(8-9)}$.

In this perspective, this study aims at reporting the construction of an information technology structure which would enable the use of NAS, considering the abovementioned issues, and discuss its applicability via cloud. It is thus expected to contribute with information and propositions which favor the reflection on Nursing knowledge construction in the area of information systems. Therefore, it aimed at describing the stages of the development of an information technology structure for the use of NAS, named NAS Cloud Technology ${ }^{\circledR}$.

\section{METHOD}

The development of a technological product based on the system life cycle theory may be subdivided into seven phases: problem recognition, viability study, analysis, detailed project, implementation, tests, and maintenance ${ }^{(10)}$.

In Problem recognition, the idea of developing a new system emerges when the user recognizes the problems through their business development means. The analysis phase occurs through the user assessment of the system. The project phase indicates the necessity of using the characteristics identified through the analysis and thinking them in terms of compatibility with a possible computerized execution. Next, the Programming phase enables structuring what was produced into programs. The test phase puts the system under assessment, firstly in its separated parts, and then in a set. In the maintenance phase, the constructed system is considered ready for implementation and production, indicating that it was accepted by the users involved in all stages ${ }^{(10)}$.

Aiming at quick filling up and productivity, the NAS Cloud Technology ${ }^{\circledR}$ was constructed for remote and collaborative access through browsers, cross-browsers (any browser: Internet Explorer, Firefox, Opera, HTML2), in a website hosted on Google sites ${ }^{\circledR}$, with profile access management, stored in cloud, in a World Wide Web 3.0 (WEB 3.0) concept and abstract component infrastructures, allocated in datacenters which share resources and corporative storage spaces $^{(11-13)}$. The institution database was protected in a business environment by Google ${ }^{\circledR}$, by the certified security and data protection devices and by the standards of the Health Insurance Portability and Accountability Act (HIPPA) ${ }^{(14-15)}$.

The study was conducted in critical care units of the Clinics Hospital of Porto Alegre (HCPA - Hospital de Clinicas de Porto Alegre), a public university hospital, administratively linked to the Ministry of Education (MEC) and academically to Universidade Federal do Rio Grande do Sul (UFRGS).It is a health reference center, with care, teaching and research actions focused on innovation and the transformation of realities. Its infrastructure is distributed into 699 inpatient beds, 54 adult ICC (Intensive Care Centers) beds, 13 pediatric ICU beds, 20 neonatal ICU beds, 47 emergency beds, and 36 surgical rooms; also, it is certified since 2013 by the Joint Commission International (JCI).

The project was approved by the Research Ethics Committee of HCPA under the protocol 35339914.6.0000.5327, via Plataforma Brasil, and abided by the precepts of Resolution 466/2021.

\section{RESULTS}

The development of NAS Cloud Technology ${ }^{\circledR}$ was based on the system life cycle theory. The nurses of the PostAnesthesia Recovery Unit (URPA - Unidade de Recuperação Pós-Anestésica) of HCPA, from the NAS implementation in 2010, have observed the necessity of informatizing it, since it demanded extensive manual records, variables calculation, the sum of the final result, and registration into the patient medical record at the end of the shift. This impaired real time analysis and the systemic perception of the unit, in addition to hindering the overall management based on immediate indicators. The NAS records were typed into the statistics service database, which implied rework and potential inconsistencies, in addition to interstices longer than 30 days, factors which 
discredited the relevance of the collection process and hindered nursing workload management at the unit.

The idealizers of the informatization process of NAS at the HCPA presented various propositions for its viability. They promoted meetings and studies with the hospital's Information Technology Management Coordination (CGTI - Coordenadoria de Gestão da Tecnologia da Informação) and the heads of ICU. The viable alternative for that moment was the creation of an information technology structure, to be tested in a pilot study at the URPA, via electronic form, which would be filled by the nurses through mobile devices, flats, or computers (Figures 1 and 2).

The project prioritized starting with the URPA, considering that this unit has five beds, at the first semester of 2013. Seven nurses were involved in this phase. The information technology structure for NAS collection used Google Drive resources such as Google Forms, Spreadsheets and Team Drive. The forms were used for information collection; the spreadsheets, as databases for the score management and dashboard publication (Figure 3). The pilot project and its assessment by the Nursing management and by the CGTI were developed until the end of 2013.

The information technology structure was discussed and improved with care nurses, welcoming their suggestions. The structure of the pre-test form was preliminarily assessed by the head of URPA. After the creation of all forms and spreadsheets, meetings were held with the CGTI experts and the critical units' managers, including URPA, Adult Intensive Care Center (ICC), Pediatric Intensive Care Unit (PICU), Neonatology, Adult Emergency and Hemodynamic Unit for system assessment, content access review, and customization based on the specificities of each service, aiming at their extension to these sectors.
Access control and profile were thoroughly discussed. Initially, restrictions to the unit data access were established, limiting it to the work sector of each nurse. However, with transparency policies and the improvement of the work process in the hospital institution at the end of 2015, access was democratized for all nurses of the critical units and care managers. In this phase, the backups were organized and regulated, establishing spaces for the historic NAS, i.e., the digitalization of the records prior to cloud system implementation, which were thus part of the historical series of the study, in addition to the backups of the current month.

The information technology structure, from its implementation in the URPA, was extended to the Adult ICC, with 4 units: ICU 1, ICU 2, ICU 3, and Cardiac surgery postoperative care, throughout 2014 , amounting to more than 50 beds.

At the beginning of 2015 , the system received more than 10,000 submissions/month and the process was extended to the ICU areas and Hemodynamics. It was implemented in the Adult Emergency and Neonatology in the second semester of 2015, amounting to 12 care units for critical patients covered by the information technology structure and more than 200 nurses per day involved in the collection, with hundreds of daily submissions, integrating the full transition from paper to cloud at the end of 2015, with the migration of the data from the NAS Cloud Technology ${ }^{\circledR}$ developer's server to the HCPA Conecta server.

The system underwent maintenances throughout the process. At the end of 2013, after pilot approval, the submission limit was extremely low comparing to the institutional demand. Each unit would have to backup their data after 100 submissions, a practice incompatible with the Adult ICU introduction to the system, since, for instance, ICU 2 alone

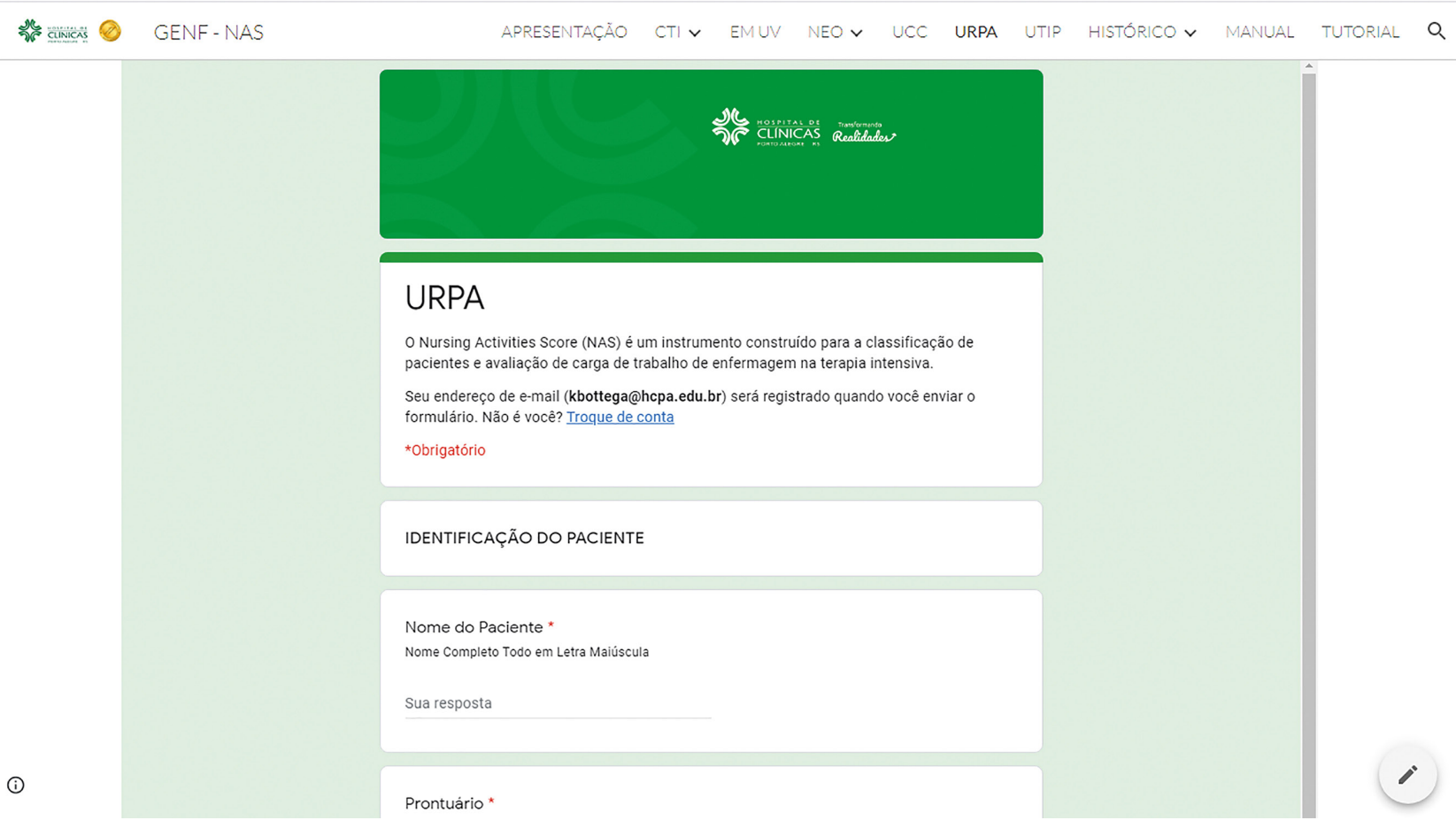

Figure 1 - Layout of Pilot URPA - NAS Cloud Technology ${ }^{\circledast}$. Patient identification - Porto Alegre, RS, Brazil, 2020. 
(i)

INTERVENÇÕES ESPECIFICAS
Intervençōes Especificas em UTI *
22. Intervençöes especificas na unidade de terapia intensiva 2,8
0
0
2,8

Intervenções Especificas Fora da UTI *

23. Intervenções especificas fora da unidade de terapia intensiva 1,9

(2) 0

1,9

Envie-me uma cópia das minhas respostas.

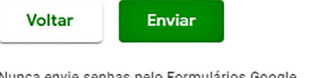

GoogleFormulários Este formulário foi criado em Hospital de Clinicas de Porto Alegre.

Figure 2 - Layout of Pilot URPA - NAS Cloud Technology ${ }^{\circledast}$. NAS records - Porto Alegre, RS, Brazil, 2020.
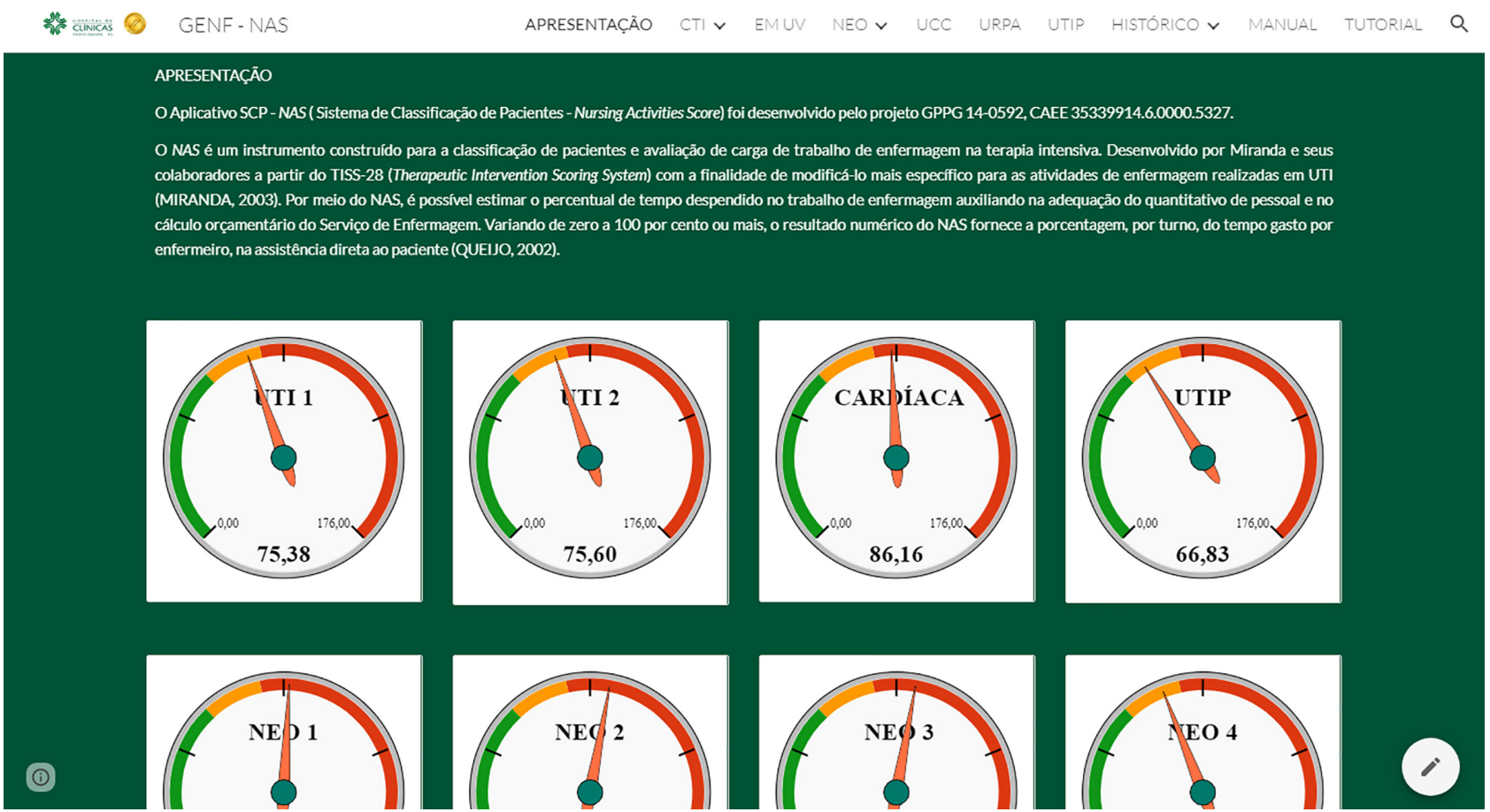

Figure 3 - Dashboard Layout - NAS Cloud Technology $y^{\oplus}$ - Porto Alegre, RS, Brazil, 2020.

would perform 99 submissions per day, surpassing the limit expected for the whole month in only one day.

In January 2014, the system was extended to a 1,500 submissions/month capacity and, in 2015 , after new problems related to the backup insufficiency due to limited human resources, the capacity was again extended to more than 10,000 submissions/month, favoring the units' management of their own records.

\section{DISCUSSION}

The project was created inside the Google Drive environment and used its applications, more specifically Google Forms, Spreadsheets and Sites, conferring more fluidity to the process of access to NAS Cloud Technology ${ }^{\circledR}$. This enables each nurse of the critical patients area to access the units' dashboard using their business email (Gmail) login, 
making the connectivity easier, without the need to create a new login and password, improving usability and making the system more user friendly ${ }^{(16)}$.

Google ${ }^{\circledR}$, holder of the applications' copyright, aims at the democratization of information through information technology-based products. Their products present excellent usability, reliability, functionality, and efficiency, and stand out for providing real time cloud collaboration, enabling simultaneously editing and collaborating on documents produced by several hands ${ }^{(14)}$.

The choice of these tools considered their similarity with Office ${ }^{\circledR}$ programs, such as Word ${ }^{\circledR}$, Excel $^{\circledR}$, and PowerPoint ${ }^{\circledR}$, in order to facilitate the interface presentation. The system should satisfy the users, providing comfort and attending their demands, in addition to being self-explanatory and comprehensible in terms of visualization. These programs are popular and mostly adopted by Windows ${ }^{\circledR}$ operational system users $^{(16)}$.

The use of information systems enables the immediate access to information and processes, contributing to Nursing care planning, as well as cost management and decision-making. Technological innovation increasingly impacts Nursing, inciting the need for its incorporation to practices and for strong contributions of information tools to care improvement ${ }^{(16-17)}$.

Nursing Activities Score, upon being systematized as a tool through Google, as a healthcare information and communication technology, has provided high productivity in the development and connection of knowledge on this theme by the involved Nursing professionals, enabling the approximation of professionals with a care and management tool, optimizing processes and making Nursing work easier.
The need to offer evidence-based support to the management activities of nursing care for critical patients enables the comprehension and incorporation of NAS, using the generated data so as to make it possible, also, the assessment of quality of care provided to patients, since such assessments depend on the availability and precision of such data ${ }^{(18-19)}$. Thus, accessing information in real time through NAS optimizes task distribution and care organization ${ }^{(10)}$.

\section{CONCLUSION}

Based on the premise that the systematized instrument could contribute to the adoption of NAS by nurses as a workload measure, the software NAS Cloud Technology ${ }^{\circledR}$ was developed in two modules: the first managerial and the second operational, expected to be used via mobile, with records through wireless and wi-fi networks.

The information technology structure was developed in an innovative and pioneer logic with the use of cloud data. The low cost for the institution, as it was a project created with Google Apps Education ${ }^{\circledR}$ tools, currently G Suite Business ${ }^{\circledR}$, and the database protected in a business environment through security and data protection devices certified by the Health Insurance Portability and Accountability Act (HIPPA) made this structure attractive for multiplication in other health institutions.

The relevancy achieved by NAS Cloud Technology ${ }^{\circledR}$ is perceived in practical terms in the continuity of its use up to the present moment in HCPA, in the deliberations regarding staff sizing and care management and its use based on the care and management practice, in addition to the possibility of adjusting the functional staff in intensive care units, referenced by the degree of care measured in the previous work shift, thus conferring safety and assertiveness to the process.

\section{RESUMO}

Objetivo: Relatar o processo de organização e construção da estrutura informatizada denominada Nursing Activities Score (NAS) Tecnologia em Nuvem ${ }^{\circledR}$. Método: Trata-se de um projeto fundamentado na teoria do ciclo de vida que, por meio da engenharia de software, permitiu o desenvolvimento de produção tecnológica. Resultados: O NAS Tecnologia em Nuvem ${ }^{\circledR}$ foi construído para acesso remoto e colaborativo em site hospedado no Google sites ${ }^{\circledR}$ e protegido em regime empresarial pelos dispositivos de segurança e proteção de dados certificados Health Insurance Portability and Accountability Act (HIPPA). Em 2015, o sistema já recebia mais de 10 mil submissões/mês, totalizando 12 unidades de atendimento a pacientes críticos cobertas pela estrutura informatizada, cerca de 200 enfermeiros envolvidos diariamente nas coletas e centenas de submissões diárias, integralizando a transição completa do papel à nuvem. Conclusão: O desenvolvimento do Sistema NAS Tecnologia em Nuvem ${ }^{\circledR}$ permitiu a utilização da tecnologia como meio facilitador para o uso de dados relacionados à assistência de Enfermagem, oportunizando ferramentas para a tomada de decisão quanto ao quantitativo de pessoal de enfermagem necessário para as demandas de cuidado das unidades de internação. Ressalta-se o potencial da utilização de estruturas em nuvem pela possibilidade de inovação, acesso mediante baixo custo e alta replicabilidade do sistema informatizado.

\section{DESCRITORES}

Informática em Enfermagem; Sistemas de Informação; Carga de Trabalho; Enfermagem; Cuidados Críticos.

\section{RESUMEN}

Objetivo: Informar sobre el proceso de organización y construcción de la estructura informática denominada Nursing Activities Score (NAS) Tecnología en Nube ${ }^{\circledR}$. Método: Se trata de un proyecto basado en la teoría del ciclo de vida que, a través de la ingeniería de software, permitió el desarrollo de la producción tecnológica. Resultados: La NAS Tecnología en Nube ${ }^{\circledR}$ se creó para el acceso remoto y colaborativo a un sitio web alojado en Google Sites ${ }^{\circledR}$ y protegido a nivel empresarial por los dispositivos de seguridad y protección de datos certificados Health Insurance Portability and Accountability Act (HIPPA). En 2015, el sistema recibía más de 10.000 envíos/mes, totalizando 12 unidades de atención de pacientes críticos cubiertas por la estructura informática, cerca de 200 enfermeros involucrados diariamente en las recolecciones y cientos de envíos diarios, integrando la transición completa del papel a la nube. Conclusión: El desarrollo del Sistema NAS Tecnología en Nube ${ }^{\circledR}$ permitió el uso de la tecnología como un medio para facilitar el uso de datos relacionados con la atención de enfermería, brindando oportunidades para herramientas de toma de decisiones sobre la cantidad de personal de enfermería necesario para las demandas de atención de las unidades de internación. Se destaca el potencial del uso de estructuras en la nube debido a la posibilidad de innovación, acceso a bajo costo y alta replicabilidad del sistema informático. 


\section{DESCRIPTORES}

Informática em Enfermagem; Sistemas de Información; Carga de Trabajo; Enfermería; Cuidados Críticos.

\section{REFERENCES}

1. Jones A, Aylward R, Jones A. Enhanced supervision: new ways to promote safety and well-being in patients requiring one-to-one or cohort nursing. Nurs Manage [Internet]. 2019 [cited 2019 Sept. 10];26(2):22-9. DOI: https://doi.org/10.7748/nm.2019.e1827.

2. Jarden RJ, Sandham M, Siegert RJ, Koziol-McLain J. Strengthening workplace well-being: perceptions of intensive care nurses. Nurs Crit Care [Internet]. 2018 [cited 2019 Sept 10];24(1):15-23. DOI: https://doi.org/10.1111/nicc.12386.

3. Torre M, Popper MCS, Bergesio A. Burnout prevalence in intensive care nurses in Argentina. Enferm Intensiva [Internet]. 2019 [cited 2019 Sept 20];30(3):108-15. Available from: https://www.sciencedirect.com/science/article/pii/S2529984019300400.

4. Miranda DR, Nap R, De Rijk A, Schaufeli W, lapichino G. Nursing activities score (NAS). Crit Care Med [Internet]. 2003 [cited 2019 Sept 20];31(2):374-82. DOI: https://doi.org/10.1097/01.CCM.0000045567.78801.CC.

5. Queijo AF, Padilha KG. Nursing Activities Score (NAS): Cross-cultural adaptation and validation to Portuguese language. Rev Esc Enferm USP [Internet]. 2009 [cited 2019 Sept 20];43(Esp):1018-25. Available from: http://www.scielo.br/pdf/reeusp/v43nspe/a04v43ns.

6. Oliveira EM, Secco LMD, Figueiredo WB, Padilha KG, Secoli SR. Nursing Activities Score and the cost of nursing care required and available. Rev Bras Enferm [Internet]. 2019 [cited 2019 Sept 27];72(Suppl1):137-42. DOI: http://dx.doi.org/10.1590/0034-7167-20170655 .

7. Brasil. Ministério da Saúde. Resolução n 7, de 24 de fevereiro de 2010 [Internet]. Brasília: Ministério da Saúde; 2010 [cited 2019 Dec 28]. Available from: http://bvsms.saude.gov.br/bvs/saudelegis/anvisa/2010/res0007_24_02_2010.html.

8. Souza VS, Oliveira JLC, Costa MAR, Vicente G, Mendonça RR, Matsuda LM. Association between safety climate and nursing workload. Cogitare Enferm [Internet]. 2019 [cited 2019 Sept 30];24:e58976. DOI: http://dx.doi.org/10.5380/ce.v24i0.58976.

9. Machado DA, Figueiredo NMA, Velasques LS, Bento CAM, Machado WCA, Vianna LAM. Cognitive changes in nurses working in intensive care units. Rev Bras Enferm [Internet]. 2018 [cited 2019 Sept 20];71(1):73-9. DOI: http://dx.doi.org/10.1590/0034-7167-2016-0513.

10. Ching FDK, Onouye BS, Zuberbuhler D. Sistemas Estruturais Ilustrados: Padrões, Sistemas e Projeto. Porto Alegre: Bookman; 2015.

11. Laudon P, Laudon KC. Sistemas de informação gerenciais. São Paulo: Pearson Prentice Hall; 2007.

12. Mendez CB, Salum NC, Junkes C, Amante LN, Mendez CML. Mobile educational follow-up application for patients with peripheral arterial disease. Rev Latinoam Enferm [Internet]. 2019 [cited 2019 Nov 11];27:e3122. DOI: http://dx.doi.org/10.1590/1518-8345.2693-3122.

13. Carrión A, Caballe M, Blanquer I, Kotowski N, Jardim R, Dávila AMR. Managing workflows on top of a cloud computing orchestrator for using heterogeneous environments on e-Science. Int J Web Grid Serv [Internet]. 2018 [cited 2019 Oct 22];13(4):1-38. DOI: https://doi. org/10.1504/IJWGS.2017.087326.

14. Sampaio A, Oliveira L, Gomes E. Teacher training in Google Drive applications challenges placed on teaching practice. Rev Estud Investig Psicol Educ [Internet]. 2017 [cited 2019 Oct 22];Extr.(13):168-71. DOI: http://dx.doi.org/10.17979/reipe.2017.0.13.2659.

15. Cheng VS, Hung PC. Health insurance portability and accountability act (HIPPA) compliant access control model for web services. Int J Healthc Inf Syst Inform [internet]. 2006 [cited 22 Oct 2019];1(1):22-39. DOI: https://doi.org/10.4018/jhisi.2006010102.

16. Ramos R, Ramos S, Asega F. Google Drive: potentialities for the design of Digital Educational Material (DEM) for language teaching. Especialist [Internet]. 2017 [cited 2019 Out. 22];38(1):1-17. DOI: http://dx.doi.org/10.23925/2318-7115.2017v38i1a6.

17. Santos RV, Terra R. The Governance of Information Technology in Hospitals improving the strategic results. J Health Inform [Internet]. 2018 [cited 2019 Oct 22];10(2):64-8. Available from: http://www.jhi-sbis.saude.ws/ojs-jhi/index.php/jhi-sbis/article/view/570/333.

18. Ahmadishad M, Adib-Hajbaghery M, Rezaei M, Atoof F, Munyisia E. Care and noncare-related activities among critical care nurses: cross-sectional observational time and motion study. Nurs Midwifery Stud [Internet]. 2019 [cited 2019 Sept 27];8:40-7. DOI: https://doi. org/10.4103/nms.nms_60_18.

19. Greaves J, Goodall D, Berry A, Shrestha S, Richardson A, Pearson P. Nursing workloads and activity in critical care: A review of the evidence. Intensive Crit Care Nurs [Internet]. 2018 [cited 2019 Sept 27];48:10-20. DOI: https://doi.org/10.1016/j.iccn.2018.06.002. 